Simbiosis Mutualisme Perpustakaan dengan Media Cetak sebagai Upaya Membudayakan Membaca dan Menulis bagi Masyrakat Muhammad Rohmadi

- Faktor Pengembangan dan Isu dalam Masalah Karier Pustakawan Masriyatun

Menguak Informasi via Alexa.com sebagai Evaluasi Menuju Optimalisasi

- Keberaksesan terhadap Perpustakaan dan Institusinya Wiji Suwarno

Profesionalisme Pustakawan dalam Layanan Informasi SriAnawati

Public Space dan Private Space: Posisi Strategis Perpustakaan dalam Mendukung

Pembelajaran Kolaboratif Purwani Istiana

Mewujudkan World-class Professionalism of Librarians di Era Library Mobile

Yuni Nurjanah

- Tantangan dan Kesiapan Pustakawan di Era Digital Dian Hapsari

Formulasi Strategi Membangun Eksistensi Perpustakaan Perguruan Tinggi

(Studi UPT Perpustakaan UNS Tahun 2015) RiahWiratningsih

Optimalisasi Perpustakaan Desa dalam Rangka Meningkatkan Pendidikan Masyarakat Bambang Hemanto

Optimalisasi Layanan Perpustakaan Perguruan Tinggi melalui Pemanfaatan Social

- Media Networking sebagai Media Komunikasi antara Perpustakaan dan Pemustaka Haryanto

Rekonstruksi Budaya Hukum Masyarakat dalam Pemulihan Pascakonflik Etnis Madura dan Melayu di Kabupaten Sambas 


\section{Jurnal \\ Pustaka Ilmiah \\ Jurnal Ilmiah UPT Perpustakaan UNS}

Jurnal Pustaka Ilmiah (JPI) sebagai media kreasi para pustakawan, guru, dosen, dan praktisi dalam pengembangan profesi secara berkelanjutan. Berbagai ide dan gagasan kreatif menjadi bahan kajian yang diimplementasikan dalam berbagai model pengembangan bahan pustaka, baik cetak maupun online. Kreativitas menjadi akar pengembangan ilmu pengetahuan sepanjang hayat dengan berbagai model pengembangan budaya literasi di perpustakaan. Keindahan dan kecermatan dalam sebuah tulisan ilmiah dan nonilmiah akan dapat direalisasikan secara nyata oleh sumber daya manusia untuk menghasilkan SDM yang unggul dan kreatif dengan membaca dan menulis untuk menyinari dunia. Budaya literasi menjadi upaya untuk pengembangan dan pemberdayaan perpustakaan sebagai pusat sumber belajar untuk mendukung tri dharma perguruan tinggi.

\section{SUSUNAN REDAKSI JURNAL PUSTAKA ILMIAH UPT PERPUSTAKAAN UNS}

Penanggung Jawab

Ketua Redaksi

Wakil Redaksi

Sekretaris

Penyunting Ahli
: Dr. Muhammad Rohmadi, M.Hum.

: Dra. Tri Hardiningtyas, M.Si.

: Haryanto, M.IP.

: Bambang Hermanto, S.Pd., M.IP., Henny Perwitosari, A.Md.

: 1. Dr. Muhammad Rohmadi, M.Hum. (Universitas Sebelas Maret);

2. Drs. Widodo, M.Soc.Sc. (Universitas Sebelas Maret);

3. Drs. Harmawan, M.Lib. (Universitas Sebelas Maret).

: Daryono, S.Sos., M.IP.; RiahWiratningsih, S.S., M.Si., Dinar Puspita Dewi, S.Sos., M.IP.; Sri Utari, S.E.

: Nurul H., A. Md.; Novi Tri Astuti, A.Md.

: Aji Hartono, A. Md.; Agus Sriyono, A.Md.; Aris Suprihadi, S.IP.

\section{DITERBITKAN OLEH UPT PERPUSTAKAAN UNS}

REDAKSI JURNAL PUSTAKA ILMIAH

Alamat: Jl. Ir. Sutami 36A Kentingan, Surakarta 57126

Telp./Fax.: (0271) 654311; email: jurnal.pustaka.ilmiah@gmail.com 


\section{PENGANTAR REDAKSI}

Salam pustaka. Dengan rasa syukur kepada allah swt. Segenap redaksi Jurnal Pustaka Ilmiah (JPI) mengucapkan banyak terima kasih kepada para penulis yang telah berkontribusi untuk penerbitan perdana JPI. Dengan terbitnya JPI ini berarti UPT Perpustakaan UNS telah memiliki media penulisan bagai para pustakawan, dosen, tenaga kependidikan, guru, dan praktisi untuk menuangkan ide dan gagasan kreatifnya secara tertulis.

Dalam penerbitan JPI perdana ini disajikan sepuluh tulisan antara lain: (1) Faktor Pengembangan dan Isu Dalam Masalah Karier Pustakawan (Masriyatun), (2) Menguak Informasi via Alexa.com sebagai Evaluasi Menuju Optimalisasi Keberaksesan terhadap Perpustakaan dan Institusinya (Wiji Suwarno), (3) Profesionalisme Pustakawan dalam Layanan Informasi (Sri Anawati), (4) Public Space dan Private Space: Posisi Strategis Perpustakaan dalam Mendukung Pembelajaran Kolaboratif (Purwani Istiana), (5) Mewujudkan World-class Professionalism of Librarians di Era Library Mobile (Yuni Nurjanah), (6) Tantangan dan Kesiapan Pustakawan di Era Digital (Dian Hapsari), (7) Formulasi Strategi Membangun Eksistensi Perpustakaan Perguruan Tinggi (Studi UPT Perpustakaan UNS Tahun 2015) (Riah Wiratningsih), (8) Optimalisasi Perpustakaan Desa dalam Rangka Meningkatkan Pendidikan Masyarakat (Bambang Hemanto), (9) Optimalisasi Layanan Perpustakaan Perguruan Tinggi melalui Pemanfaatan Social Media Networking sebagai Media Komunikasi antara Perpustakaan dan Pemustaka (Haryanto).

Akhirnya, redaksi JPI mengucapkan banyak terima kasih kepada Kepala UPT Perpustakaan UNS yang telah memberikan dukungan dan memfasilitasi untuk penerbitan JPI. Selain itu, ucapan terima kasih juga disampaikan kepada para penulis, tim redaksi, dan Yuma Pressindo, yang telah mempersiapkan dari awal sampai terbitnya JPI.

Desember 2015

Ketua Redaksi, 


\section{SAMBUTAN}

Dr. Muhammad Rohmadi, M.Hum.

Kepala UPT Perpustakaan UNS

\section{“Jadikalah tulisanmu sebagai cermin kehidupanmu di masa sekarang dan masa depan"}

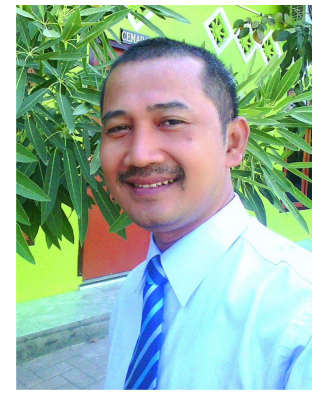

Selamat dan sukses atas diterbitkannya Jurnal Pustaka Ilmiah (selanjutnya disingkat JPI). Sambutan ini diberikan dalam rangka penerbitan perdana JPI. Jurnal ini sebagai media kreativitas dan pengembangan softskill para pustakawan, guru, dosen, dan praktisi untuk menuangkan ide dan gagasan dalam berbagai konteks kehidupan. Berbagai isu terkait dengan pengembangan perpustakan, pusat sumber belajar, pendidikan, dan budaya literasi akan menjadi topik-topik yang disajikan dalama jurnal ilmiah ini.

Diterbitkannya JPI sebagai bukti kepedulian UPT perpustakaan Ilmiah dalam rangka turut berpartisipasi untuk mengembangkan dan membudayakan literasi untuk para pustakawan dan civitas akademika di UNS dan luar UNS. Berbagai model pengembangan softskill menjadi alaternatif untuk membekali dan memperkuat jaringan kerja sama penulisan antarkelembagaan. Dengan demikian, kerja sama antarpustakawan dan pemustaka dapat diwujudkan dengan berbagai model dalam bidang literasi.

Penerbitan JPI sebagai upaya untuk memotivasi semua pustakawan menulis, baik ilmiah maupun nonilmiah. Para pustakawan harus menjadi pionir dalam bidang penulisan. Hal ini sebagai bentuk kepedulian dan keteladaan para pustakawan yang memproses, menyajikan, dan menikmati bahanbahan pustaka cetak dan noncetak di perpustakaan. Ketersedian bahan pustaka akan menjadi bahan paling nyata untuk dikembangkan dalam berbagai model perwujudan teknik peniulisan. Hal terpenting yang harus dimiliki oleh para pustakawan adalah semangat untuk berbagai pengetahuan melalui tulisan.

Kepedulian setiap sumber daya manusia kepada kelembagaan dapat dituangkan dalam berbagai model pengabdian, salah satunya adalah melalui tulisan. Berbagai ide dan gagasan dapat direalisasikan dengan berbagai model bentuk artikel jurnal, buku, modul, monograf, dan lain sebagainya. Para civitas akademika, guru, praktisi harus memiliki keterampilan menulis sebagai bentuk perwujudan pengembangan diri secara berkelanjutan. Berbagai tulisan dan referensi sudah disajikan tetapi masih sangat minim untuk diimplementasikan dalam kehidupan. Banyak orang pandai dalam berbicara tetapi masih sedikit yang menuangkan ide dan gagasannya dalam bentuk tulisan.

Akhirnya, keluarga besarUPT Perpustakaan UNS mengucapkan banyak terima kasih kepada Rektor, Wakil Rektor, pengelola JPI, penulis, dan semua pihak yang telah mendukung penerbitan perdana JPI. Semoga dengan diterbitkannya JPI ini dapat menjadi media untuk menulis para pustakawan, dosen, guru, dan praktisi dalam bidang iptek dan seni. Ucapan terima kasih juga diucapkan kepada percetakan Yuma Pressindo yang telah membantu mempersiapkan dari awal sampai terbitnya JPI ini. Akhirnya, semoga JPI dapat memberikan nilai kemaslahatan untuk umat.

“Berdiri kemudian berbaring sangatlah cepat tetapi tatkala sudah dituliskan akan menjadi kenangan yang taidak terlupakan sepanjang hayat”

Surakarta, Desember 2015 


\section{DAFTAR ISI \\ JURNAL PUSTAKA ILMIAH EDISI 1 VOLUME 1 TAHUN 2015}

Simbiosis Mutualisme Perpustakaan dengan Media Cetak sebagai Upaya Membudayakan Membaca dan Menulis bagi Masyrakat

Muhammad Rohmadi

Faktor Pengembangan dan Isu dalam Masalah Karier Pustakawan.

Masriyatun

Menguak Informasi via Alexa.com sebagai Evaluasi Menuju Optimalisasi Keberaksesan terhadap Perpustakaan dan Institusinya

Wiji Suwarno

Profesionalisme Pustakawan dalam Layanan Informasi

Sri Anawati

Public Space dan Private Space: Posisi Strategis Perpustakaan dalam Mendukung Pembelajaran Kolaboratif

Purwani Istiana

Mewujudkan World-class Professionalism of Librarians di Era Library Mobile

Yuni Nurjanah

Tantangan dan Kesiapan Pustakawan di Era Digital

Dian Hapsari

Formulasi Strategi Membangun Eksistensi Perpustakaan Perguruan Tinggi (Studi UPT Perpustakaan UNS Tahun 2015)

Riah Wiratningsih

Optimalisasi Perpustakaan Desa dalam Rangka Meningkatkan Pendidikan Masyarakat Bambang Hemanto

Optimalisasi Layanan Perpustakaan Perguruan Tinggi melalui Pemanfaatan Social Media Networking sebagai Media Komunikasi antara Perpustakaan dan Pemustaka Haryanto 


\title{
OPTIMALISASI LAYANAN PERPUSTAKAAN PERGURUAN TINGGI MELALUI PEMANFAATAN SOCIAL MEDIA NETWORKING SEBAGAI MEDIA KOMUNIKASI ANTARA PERPUSTAKAAN DAN PEMUSTAKA
}

\begin{abstract}
Haryanto
ABSTRAK

Terbatasnya layanan perpustakaan oleh jarak dan waktu membuat pustakawan berkreativitas dengan memanfaatkan media sosial dalam memberikan layanan. Media sosial merupakan media yang dapat digunakan oleh perpustakaan untuk promosi, informasi, transaksi, silaturahmi, komunikasi, berbagi atau sharing, dan juga pengembangan diri. Dengan media sosial, perpustakaan dapat membuat grup yang digunakan untuk mengorganisasi pemustaka sehingga komunikasi antara pemustaka dan perpustakaan dapat dilakukan dengan optimal. Agar media sosial untuk layanan perpustakaan perguruan tinggi berjalan efektif, diperlukan penyediaan sumber daya manusia yaitu pustakawan atau staf perpustakaan (admin) yang khusus bertugas memantau media sosial milik perpustakaan, tata tertib grup dibuat oleh perpustakaan, kemampuan pustakawan dalam penelusuran informasi yang tidak terbatas pada koleksi di tempatnya, dan nomor rekening perpustakaan. Dengan berbagai ketentuan tersebut, komunikasi antarperpustakaan dan pemustaka akan berjalan dan media sosial dapat digunakan sebagai media komunikasi untuk memenuhi kebutuhan informasi pemustaka secara optimal.
\end{abstract}

Kata kunci: media sosial, optimalisasi layanan, perpustakaan perguruan tinggi

\section{PENDAHULUAN}

Sumber daya merupakan hal pokok yang harus dimiliki perpustakaan agar dapat lebih optimal memberikan layanan, baik sumber daya manusia maupun sumber daya teknis. Dengan sumber daya yang memadai, diharapkan akan terjalin komunikasi antara perpustakaan dan pemustaka sehingga mempermudah sharing informasi. Pada umumnya sistem pembelajaran di perguruan tinggi menerapkan sistem pembelajaran yang memungkinkan mahasiswa mengembangkan diri melalui informasi yang dimiliki seluas- luasnya dengan berbagai sumber informasi sehingga informasi berupa koleksi yang dimiliki perpustakaan di perguruan tinggi sangat berpengaruh dalam pendidikan mahasiswa karena secara tidak langsung memberikan input pada penyerapan ilmu. Dengan terbatasnya sumber daya, layanan menjadi tidak maksimal sehingga menuntut adanya kreativitas dari pihak pustakawan. Media komunikasi seringkali menjadi kendala pustakawan dalam meberikan layanan.

Layanan perpustakaan seringkali terbentur oleh jarak yang jauh dengan pemustaka dan jam buka perpuystakaan yang terbatas. Sampai saat ini sebagian besar perpustakaan rata-rata menerapkan jam buka 'standar", yaitu pagi sampai siang maupun sore dengan jeda waktu istirahat sehingga tidak optimal dalam pemberian layanannya, belum lagi dengan berbagai aktivitas pustakawan saat ini yang makin disibukkan dengan pekerjaan administrasi maupun tugas tambahan yang menyita waktu dalam memberikan layanan kepada pemustaka. Akibatnya, komunikasi 
pustakawan dengan pemustaka menjadi tidak efektif sehingga mempengaruhi layanan yang dapat diberikan oleh perpustakaan padahal banyak mahasiswa ingin berkonsultasi atau bertanya perihal kebutuhan literacy. Untuk itu, diperlukan suatu media komunikasi yang aktif 24 jam, yang dapat digunakan untuk mengomunikasikan suatu permintaan informasi disertai dukungan fasilitas untuk share informasi digital, mengingat saat ini informasi berupa material digital makin banyak ragamnya, seperti e-journal dan e-book. Diperlukan suatu media komunikasi efektif yang dapat digunakan pustakawan untuk memberikan layanan yang tidak terbatas jarak dan waktu.

Salah satu bentuk perkembangan teknologi adalah dengan lahirnya media sosial yang saat ini mengubah perilaku komunikasi dan sosial dalam masyarakat umum maupun profesi. Munculnya media sosial menjadikan komunikasi dapat dilakukan seperti tanpa batas jarak dan waktu. Dengan media sosial, dimungkinkan untuk membentuk komunitas berupa grup-grup atau kelompok yang dapat share informasi. Dengan berbagai kelebihan tersebut, media sosial saat ini marak dijadikan tempat pustakawan membentuk grup atau komunitas dengan pemustakanya dengan berbagai tujuan. Tujuan tersebut di antaranya sebagai ajang promosi, informasi, transaksi, silaturahmi, komunikasi, berbagi atau sharing, dan juga pengembangan diri.

Situs jejaring sosial didefinisikan sebagai layanan berbasis web yang memungkinkan individu untuk membangun profil publik atau semi publik dalam sistem yang dibatasi, mengatur daftar pengguna lain dengan siapa mereka berbagi koneksi, melihat dan menavigasi daftar koneksi dan yang dibuat oleh orang lain dalam sistem (Boyd \& Ellison, 2007). Powel (2009) mendefinisikan jaringan media sosial sebagai sebuah komunitas yang terhubung melalui persahabatan, nilai-nilai, hubungan, ide, dan pekerjaan. Seufert, et. al. (1999) mendefinisikan situs jejaring sosial sebagai sejumlah orang, sumber daya, dan hubungan di antara mereka, yang dirakit dalam rangka mengumpulkan dan menggunakan pengetahuan, terutama melalui penciptaan pengetahuan dan mentransfer proses dengan tujuan menciptakan nilai. Konsep jaringan sosial adalah salah satu dari alat-alat Web 2.0, yang juga membentuk dasar perpustakaan 2.0. Kaplan \& Haenlein (2010) mendefinisikan media sosial sebagai sebuah kelompok aplikasi berbasis internet yang dibangun di atas dasar ideologi dan teknologi Web 2.0 dan yang memungkinkan penciptaan dan pertukaran user-generated content.

Dari berbagai definisi di atas, dapat disimpulkan bahwa media sosial berupa social networking adalah web platform, di mana orangorang dari budaya yang berbeda pengaturan dapat terhubung dan berinteraksi satu sama lainnya. Saat ini, banyak pemanfaatan grupgrup di media sosial, seperti facebook berupa forum komunikasi pustakawan dengan dasar komunitas sama-sama pustakawan. Namun, masih sedikit perpustakan yang memanfaatkan media sosial untuk memperluas layanannya padahal forum komunikasi tersebut mempunyai banyak sisi positif bagi masing-masing anggota. Untuk itu, perlu ditelaah manfaat serta berbagai keuntungan dalam pemanfaatan media sosial sebagai media komunikasi perpustakaan dengan pemustaka untuk mendukung resources sharing koleksi di perguruan tinggi. Dalam artikel ini, penulis menganalisis salah satu media sosial yang dalam penggunaannya, masih menduduki nomor satu di Indonesia, yaitu facebook. Facebook telah memiliki lebih dari 750 juta pengguna aktif pada tahun 2011 (Facebook, 2011) dan merupakan media social networking dengan pengguna terbesar di seluruh dunia.

\section{PEMBAHASAN}

Media sosial merupakan situs di mana setiap orang bisa membuat webpage pribadi, kemudian terhubung dengan teman-teman untuk berbagi informasi dan berkomunikasi. Media sosial 
terbesar, di antaranya facebook, myspace, dan twitter. Jika media tradisional menggunakan media cetak dan media broadcast, maka media sosial menggunakan internet dalam jaringannya sehingga tak terbatas areanya. Media sosial mengajak siapa saja yang tertarik untuk berpartisipasi dengan memberi kontribusi dan feedback secara terbuka, memberi komentar, serta membagi informasi dalam waktu yang cepat dan tak terbatas. Perkembangan teknologi informasi menjadikan pertumbuhan gadget makin beragam, canggih dan murah, media sosial pun ikut tumbuh dengan pesat karena dapat diakses dari berbagai gadget tersebut. Kini untuk mengakses facebook atau twitter, bisa dilakukan di mana saja dan kapan saja hanya dengan menggunakan sebuah smartphone, handphone, atau tablet. Demikian cepatnya orang bisa mengakses media sosial, mengakibatkan terjadinya fenomena besar terhadap arus informasi, tidak hanya di negara-negara maju, tetapi juga di Indonesia. Karena kecepatannya, media sosial juga mulai tampak menggantikan peranan media massa konvensional dalam menyebarkan beritaberita dan media berkomunikasi, baik personal, berkelompok, atau komunitas.

Menurut O’Dell (2010), media sosial selain sebagai media yang efektif dan inovatif dalam menghubungkan perpustakaan dengan pemustaka, juga efektif dan inovatif dalam menghubungkan antarpustakawan dalam penelusuran informasi dan resources sharing. Resources sharing perpustakaan merupakan suatu usaha berbagi sumber daya berupa koleksi perpustakaan. Kendala dalam resources sharing terletak pada kurangnya media komunikasi antarpustakawan dengan pemustaka yang seringkali terpisah jarak yang jauh dan waktu yang terbatas.

Media sosial seringkali dipakai pustakawan dengan tujuan menjadi bagian dari komunitasnya (De Rosa, et.al., 2007) atau mempromosikan layanan dan kegiatan perpustakaan (Charnigo
\& Barnett-Ellis, 2007). Sampai saat ini, banyak sekali grup-grup dalam media sosial yang telah dibentuk pustakawan berdasarkan profesi, jenis perpustakaan, maupun minat. Akan tetapi, grup yang didasari oleh suatu perpustakaan mengorganisasi pemustakanya masih minim. Padahal jika dioptimalkan, group semacam ini atau webpage media sosial yang dimiliki suatu perpustakaan akan dapat memberikan layanan secara ekslusif karena dapat secara langsung request informasi selain dari pihak perpustakaan yang dapat mempromosikan berbagai layanan dan koleksi. Interaksi yang terjadi antara perpustakaan, dalam hal ini pustakawan dengan pemustaka, melalui media sosial akan meningkatkan layanan kepada pemustaka dalam memenuhi kebutuhan informasi. Sharing pengetahuan merupakan aspek penting untuk perpustakaan menggunakan media sosial sejak perpustakaan berperan dalam sharing pengetahuan (MacAdam, 1998). Media sosial seperti facebook sangat efektif dipakai sebagai media komunikasi yang digunakan pustakawan untuk berhubungan dengan pemustaka karena memenuhi beberapa aspek, di antaranya:

1. Mampu membuat grup yang didasari oleh suatu persamaan atau keanggotaan.

2. Accessible kemudahan diakses melalui berbagai media online dengan berbagai gadget.

3. Dapat digunakan untuk saling berkirim dan share berbagai jenis file.

4. Terdapat log atau data komunikasi atau kronologis sebagai pengingat.

5. Mampu menjadi media promosi koleksi yang dimiliki perpustakaan dengan cara memposting koleksi tersebut. Selain itu, dapat digunakan untuk request informasi.

6. Dapat digunakan untuk berkomunikasi personal maupun bersifat public antara pustakawan dengan pemustaka, misalnya dalam hal perpanjangan peminjaman maupun request informasi. 
Dalam pemanfaatan media sosial agar dapat dipakasi sebagai media komunikasi yang efektif oleh perpustakaan dengan pemustaka agar dapat mendukung penelusuran informasi dan share informasi pada suatu grup pemustakamogen diperlukan berbagai hal, di ataranya:

1. Penyediaan sumber daya manusia yaitu pustakawan atau staf perpustakaan (admin) yang khusus bertugas memantau media sosial milik perpustakaan yang akan menjadi admin utama yang memberikan jawaban setiap pertanyaan dan memberikan informasi dari perpustakaan kepada pemustaka. Keahlian akan media sosial dan komunikasi, serta kemampuan akan teknologi informasi merupakan skill utama yang harus dimiliki karena profesi ini dalam kesehariannya akan mengelola anggota yang banyak serta share resources berkaitan dengan alih media suatu jurnal maupun free book.

2. Tata tertib dalam grup yang dibuat oleh perpustakaan harus disepakati atau ditaati oleh anggota. Perpustakaan bisa me-remove anggota yang tidak menaati peraturan atau kesepakatan. Dalam resources sharing, agar kegiatan berjalan dengan lancer, sebelumnya harus dibuat kesepakatan dengan tidak mengabaikan peraturan hak cipta, e-journal, dan e-book yang hanya dapat di-share, sedangkan koleksi tercetak buku yang tidak ada versi digitalnya hanya di-LAN-kan sebatas informasi bibliografi.

3. Kemampuan pustakawan dalam penelusuran informasi yang tidak terbatas pada koleksi di tempatnya untuk mensupport admin dalam memberikan jawaban bagi pemustaka. Dengan menggunakan media sosial untuk berkomunikasi dengan pemustaka, dimungkinkan adanya permintaan informasi sumber belajar yang harus dicarikan di tempat lain. Untuk itu, sebelum membuka layanan perpustakaan menggunakan media sosial, pustakawan harus dibekali kemampuan untuk mengakses informasi dari banyak sumber agar ia dapat memberikan informasi yang dikehendaki oleh pemustaka.

4. Dalam resources sharing, pihak yang membutuhkan seringkali diharuskan mengganti biaya fotokopi dan biaya pengiriman material fotokopi. Jika ada nomor rekening perpustakaan, maka transaksi akan lebih mudah dan jelas.

Dengan memanfaatkan media sosial untuk berkomunikasi atau beriteraksi antara perpustakaan dengan pemustaka, layanan koleksi diharapkan tidak hanya terbatas pada koleksi yang dimiliki suatu perpustakaan, tetapi dapat menghilangkan hambatan jarak untuk mendayagunakan perpustakaan. Pihak pemustaka bisa membuat status atau personal message ketika memerlukan suatu literatur atau dapat juga saling share koleksi sehingga dapat berbagi koleksi dengan pemustaka lain. Pihak perpustakaan yang memantau media sosial miliknya akan melakukan penelusuran informasi, kemudian menginformasikan material yang dimiliki atau diperoleh, kemudian dapat dilakukan tahap selanjutnya. Kalo e-resources, dapat langsung dikirimkan melalui media sosial; kalau koleksi tercetak, dapat dilakukan pengiriman via ekspedisi dengan kesepakatan biaya sebelumnya.

Komunikasi yang terjalin antarpustakawan dan pemustaka yang dijembatani media sosial perguruan tinggi merupakan network yang penting mengingat kebutuhan informasi yang sangat tinggi di perpustakaan perguruan tinggi harus diimbangi dengan layanan yang tidak terbatas, baik jam buka maupun jarak antara perpustakaan dengan pemustaka.

\section{PENUTUP}

Pemanfaatan media sosial untuk layanan perpustakaan merupakan kreativitas pustakawan dalam memberikan layanan. Dalam dunia perpustakaan, media sosial berupa facebook sangat efektif digunakan 
untuk meningkatkan layanan perpustakaan karena penggunaan facebook sebagai media komunikasi, menjadikan perpustakaan sebagai institusi yang dapat memberikan layanan yang tidak terbatas oleh jarak dan waktu. Media sosial dapat dilakukan untuk promosi, informasi, transaksi, silaturahmi, komunikasi, berbagi atau sharing, dan media pengembangan diri bagi pihak perpustakaan maupun pemustaka. Resources sharing perpustakaan merupakan suatu usaha berbagi sumber daya berupa koleksi perpustakaan untuk memenuhi kebutuhan pemustaka. Dalam resources sharing, seringkali terkendala oleh media yang kurang efektif. Namun, dengan penggunaan media sosial seperti facebook, pihak perpustakaan yang telah mempunyai grup, anggotanya dapat share bermacam koleksi, seperti e-book maupun e-journal.

Agar dalam memanfaatkan media sosial untuk resources sharing perpustakaan perguruan tinggi berjalan efektif, diperlukan penyediaan sumber daya manusia, yaitu pustakawan atau staf perpustakaan (admin) yang khusus bertugas memantau media sosial milik perpustakaan, yang akan menjadi admin utama yang memberikan jawaban setiap pertanyaan dan memberikan informasi dari perpustakaan kepada pemustaka, tata tertib dalam grup yang dibuat oleh perpustakaan harus disepakati atau ditaati oleh anggota, kemampuan pustakawan dalam penelusuran informasi yang tidak terbatas pada koleksi di tempatnya untuk men-support admin dalam memberikan jawaban kepada pemustaka, dan pengadaan nomor rekening perpustakaan. Dengan berbagai ketentuan tersebut, maka komunikasi antarperpustakaan dan pemustaka akan berjalan secara efektif dan media sosial dapat digunakan sebagai media komunikasi untuk memenuhi kebutuhan informasi pemustaka secara optimal.

\section{DAFTAR PUSTAKA}

Boyd, D. M. \& Ellison, N. B.. 2007. "Social Network Sites:Definition, History, and Scholarship". Journal of Computer-Mediated Communication, 13(1), pp: 210 - 230.

Charnigo, L. \& Barnett-Ellis, P.. 2007). "Checking Out Facebook.com: The Impact of a Digital Trend on Academic Libraries". Information Technology and Libraries, 26(1), pp: 23 - 34.

De Rosa, C., Cantrell, J., Havens, A., Hawk, J., Jenkins, L.,Gauder, B., Cellentani, D.. 2007. Sharing, Privacy Andtrust in Our Networked World: A report to the OCLC Membership. Dublin, OH: OCLC Online Computer Library Center.

Facebook. 2011. Factsheet Retrieved 08/20, 2011, from http://www.facebook.com/press/info. php?factsheet

Kaplan, Andreas M. \& Haenlein, Michael.. 2010. "Users of the world, unite! The challenges and opportunities of Social Media”. Business Horizons, 53(1), pp: 59 - 68

MacAdam, B.. 1998. "Creating Knowledge Facilities for Knowledge Work in the Academic Library”. Library Hi Tech, 16(1), pp: 91 - 99.

O’Dell, S.. 2010. “Opportunities and Obligations for Libraries in a Social Networking Age: A Survey of Web 2.0 and Networking Sites". Journal of Library Administration, 50(3), pp: $237-251$. 
Powell, Juliette. 2009. "33 Million People in The Room: How to Create, Influence, and Run a Successful Business with Social Networking”. Pearson Education, Inc., from https:// idv. sagapub.com/cgi/content/abstract/23/4/266

Seufert, Andreas, Georg, Von Krogh \& Andrea, Bach. 1999. "Towards Knowledge Networking”. Journal of Knowledge Management, 3(3), pp: 180 - 190. 